Rabaska

Revue d'ethnologie de l'Amérique française

\title{
Commentaire [suite à la réponse au compte rendu de Ronald Labelle]
}

\section{Ronald Labelle}

Volume 2, 2004

URI : https://id.erudit.org/iderudit/201689ar

DOI : https://doi.org/10.7202/201689ar

Aller au sommaire du numéro

Éditeur(s)

Société québécoise d'ethnologie

ISSN

1703-7433 (imprimé)

1916-7350 (numérique)

Découvrir la revue

Citer ce document

Labelle, R. (2004). Commentaire [suite à la réponse au compte rendu de Ronald Labelle]. Rabaska, 2, 273-274. https://doi.org/10.7202/201689ar d'utilisation que vous pouvez consulter en ligne.

https://apropos.erudit.org/fr/usagers/politique-dutilisation/ 


\section{Commentaire}

Dans leur réplique à mon compte rendu du Conte populaire français : contes-nouvelles, Nicole Belmont et Josiane Dru m'accusent d'avoir abordé l'ouvrage de Marie-Louise Tenèze avec suspicion et hostilité. Mon texte n'était pourtant pas écrit dans un esprit de suspicion et encore moins avec hostilité. J'avais d'ailleurs publié dans le Journal of American Folklore (vol. 92, $\mathrm{n}^{\circ}$ 363, 1979, pp. 94-96) un compte rendu des plus élogieux du Conte populaire français - tome troisième. Mes propos visaient simplement à poser des questions légitimes se rapportant aux nombreuses lacunes constatées dans le 
catalogue des contes-types 850 à 999 . N. Belmont et J. Dru identifient comme mon principal reproche celui que l'auteur n'ait « pas fait un catalogue du conte populaire du Canada francophone $»$. En lisant mon compte rendu, on s'aperçoit bien que je ne faisais que questionner le caractère incomplet des références aux versions de contes publiés en Amérique du Nord. La question principale posée dans le compte rendu concernait plutôt l'absence d'une décomposition en éléments des contes-types les plus importants dans la catégorie des contes-nouvelles.

Ronald LaBELLE

Université de Moncton 